Tips om medisinsk litteratur, andre bøker, filmer og elektroniske medier > som bør anmeldes, sendes tidsskriftet@legeforeningen.no

\section{Praktisk og godt om cøliakimat}

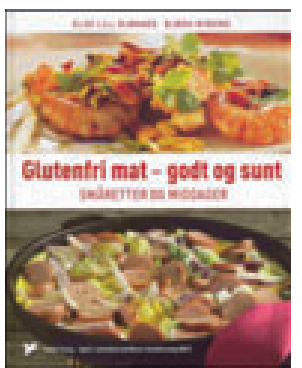

Else Lill Bjønnes, Bjørn Wiborg

Glutenfri mat - godt og sunt

Småretter og middager. 255 s, tab, ill.

Oslo: Kolibri Forlag, 2010. Pris NOK 349

ISBN 978-82-791-0303-7

Boken har et fargerikt og tiltalende ytre. Omslaget er stivt og glatt, så boken tåler å være på kjøkkenet. Den er rikt illustrert med lekre matbilder, og papirkvaliteten er god. Tekstrammer og oversiktssider med egen fargebakgrunn gir boken et variert og innbydende totalinntrykk.

De første 55 sidene er en svært god og faglig oppdatert innføring i cøliaki og de praktiske konsekvenser av å ha sykdommen, forfattet av tre kolleger, som er kjente «veteraner» innen cøliakiopplysning. Relasjonen mellom cøliaki og diabetes og dermatitis herpetiformis drøftes, og det er en enkel og god gjennomgang av cøliaki kontra hveteallergi. Det konstateres at ren havre er glutenfri og at de aller fleste cøliakere, men ikke alle, tåler ren havre. At forfatterne av denne første delen kan sitt stoff, viser de mange praktisk betydningsfulle opplysningene. For eksempel oppfordres det til at man bør bestille glutenfri kost på fly når flybilletten bestilles, men at dette ikke alltid fungerer. Dessuten oppfordres det til at cøliakere melder seg inn i Norsk Cøliakiforening, hvilket jeg, som selv er cøliaker, slutter meg varmt til. Boken er for øvrig utgitt i samarbeid med denne foreningen.

Selve oppskriftene, som utgjør hoveddelen, er praktisk inndelt i kapitler: Brød, Forretter, Småretter, Middager, Sauser osv. Praktiske opplysninger krydrer selve oppskriftene. Jeg har ikke prøvd alle oppskriftene, men umiddelbart virker de gode og praktiske. Det er en del oppskrifter med liten cøliakirelevans, f.eks. varm potetsalat, svineribbe og kokt torsk med lever, som er oppført som egne oppskrifter. Under brødoppskrifter savner jeg oppskrifter på brød bakt i ulike typer bakemaskin. Det er det ikke så enkelt å lykkes med. Det nevnes i én enkelt setning at en bakemaskin kan være praktisk. Slike brødoppskrifter bør komme med i neste, reviderte opplag.

Innholdsfortegnelsen er god og detaljert, og bakerst er det både et register som henviser fra oppskrifter til de enkelte kapitler samt et alfabetisk oppskriftsregister.

Boken anbefales varmt for alle cøliakere og deres nærmeste.

\section{Karsten Kronholm}

Ruspoliklinikken

Hamar DPS

\section{Innsiktsfullt om epilepsi}

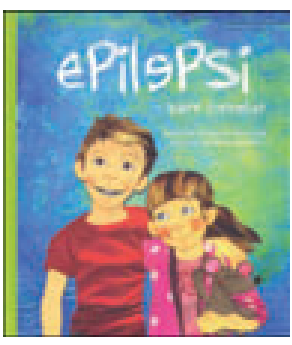

\section{Mia Tuft \\ Epilepsi - barn forteller}

Historier fortalt av barn med epilepsi og deres søsken. 56 s, ill. Oslo: Oslo

universitetssykehus, 2010. Pris ikke oppgitt

ISBN 978-82-93443-1-9

Dette er ikke først og fremst en bok for barn med epilepsi. Det er en bok for familier med barn som har epilepsi - for foreldre, søsken, venner og for andre nærpersoner. Den er utformet som en barnebok; den er tiltalende og lettlest med fine farger og tegninger. Boken favner vidt. Den egner seg for høytlesning til mindre barn, men stilen er delvis «kul» og kan også leses av litt eldre barn og ungdommer.

Ved første blikk kan den virke litt usammenhengende og banal. Budskapet kan nok virke uklart for dem som har lite kjennskap til epilepsi. Her finnes mye informasjon, men det er ingen faktabok. Boken handler om tanker og følelser ved epilepsi. Et viktig faktum går imidlertid igjen som en rød tråd: Epilepsi er ikke én sykdom, men mange ulike tilstander som arter seg på mange forskjellige måter. Dette er en viktig erkjennelse i møte med barn som er rammet av epilepsi. Forfatteren gir gjennom historiene gode innblikk i hvordan det kan være å ha epilepsi.

Kanskje er ikke ordbruken helt troverdig med tanke på at dette er lagt i munnen på barn, men fortellingene er korte og enkle. Boken har imidlertid dybde og flere plan. For at man skal få skikkelig godt utbytte er nok tilgang på ressurssterke voksne en forutsetning. De voksne må imidlertid ikke nødvendigvis være foreldre. De kan også være fagfolk som jobber med barn med epilepsi. En viktig hensikt synes å være å oppnå kontakt og dialog om tanker og problemer knyttet til sykdommen. Alle barn og familier med epilepsi vil finne noe som berører dem, og som de kan snakke videre om. Det enkle arbeidsheftet som er vedlagt, er en god idé som kan åpne opp for å kunne sette navn på vanskelige ting og for egen bearbeiding.

På en lett og dagligdags måte sveiper forfatteren innom mange aspekter: symptomenes mangfoldighet, bivirkninger av behandlingen, undersøkelsesmetoder, epilepsikirurgi, frykt, håp, fordommer, stigmatisering og restriksjoner som følge av sykdommen. Også andre symptomer og tilstander som kan ledsage epilepsi, slik som autisme, utviklingshemning og motoriske utfall, får sin plass. Mange vanskelige situasjoner blir beskrevet med en gjennomgående grei og oppmuntrende tone, ofte med en porsjon humor, uten at det virker bagatelliserende. Det er åpenbart at de som har satt sammen disse historiene, har bred erfaring med familier som er rammet av epilepsi.

Jeg anbefaler boken for alle som ønsker utveksling av tanker og samhandling med barn som har vansker med epilepsi.

Eylert Brodtkorb

Avdeling for nevrologi og klinisk nevrofysiologi St. Olavs hospital 